\title{
HEALTHY SMILE PREVENTION PROJECT IN SLOVAKIA WITH STUDENTS DH KLINIK IN PRESOV. FINAL REPORT OF STUDY: CARIOSITY OF TEETH AMONG SCHOOLCHILDREN WITHIN TWO GROUPS IN SLOVAKIA IN 2002, 2005, 2007 AND 2009
}

\author{
Eva Koval’ová, Anna Eliašová, Peter Adamišin, Alexander Koval
}

Faculty of Public Health, Faculty of Management, University of Prešov, Slovakia

Koval'ová E., Eliašová A., Adamišin P., Koval A. (2015), Healthy Smile Prevention Project in Slovakia with students DH Klinik in Presov. Final report of study: cariosity of teeth among schoolchildren within two groups in Slovakia in 2002, 2005, 2007 and 2009. Health Problems of Civilization, 2 (9), p. 27-30.

Summary: In the thesis the authors present complex results of the epidemiological study of oral health of the 6 - 12-year old schoolchildren attending elementary schools in Prešov (Slovakia) who participated in the Healthy Smile Prevention Project. The participants of the Project were represented by the pre-school children and schoolchildren from the age of 4 years attending the pre-school facilities and elementary schools and the project was performed by the dental hygienist, dental disease prevention officer, and school dental care assistant under supervision of a dental practitioner. The oral health of the abovementioned project participants was compared with the oral health of the group of children not participating in the prevention project. The project was supported by the Swiss company GABA.

$\underline{\text { Key words: }}$ cariosity of teeth, prevention, project, pre-school children, schoolchildren

\section{Present state of issue in question}

By the year 2000 the objectives of the WHO in the field of the oral heath of children at the age from 5 to 18 years were not met, yet by contraries the condition of the dentition of children is getting worse after disintegration of the "school dentist's offices" (Seppä 2001). The principal aim of the experts is directed towards preparation and implementation of the prevention projects in order to change the "trend" mentioned above (Jordan, Fedurcová et al., 2010; Klamárová 2012). The principle of prevention regarding the oral health stems from providing the children with the basic rules concerning the correct teeth cleaning, strengthening of resistance of hard dental tissues by means of fluoride as well as providing the information regarding the causes of the dental caries formation therethrough the responsibility for oral health is passed into the hands of the individual patients (Toumba, Curzon 1998).

The Healthy Smile Project belongs to the group of prevention projects successfully implemented. The principal objective of the project is education of the school dental care assistants (further on referred to as SDCA) and support of the dental hygiene education in Slovakia. The SDCA provides instructions concerning the oral health of children attending the pre-school facilities, elementary schools, and institutes by means of repetitive practice 6 times in one class in the course of one school year. The aim of the practice is to instruct the children about correct teeth and gums care and thus gradually contribute to the decrease of cariosity in Slovakia (Klamárová 2012, Seppä 2001). The aim is possible to be reached only through becoming aware of the causes of the disease genesis and by means of one's own responsibility. The facts mentioned above represent the central idea of the aim.

\footnotetext{
Address for correspondence: Eva Kovalová, Civic association Healthy Smile, Kapušianska 2, 08006 Prešov 6, Slovak Republic, e-mail: kovalova@nextra.sk

Tables: 0 Figures: 2 References: 7 Full-text PDF www.hpc.edu.pl Copyright (C) Pope John Paul II State School of Higher Education in Biała Podlaska, Sidorska 95/97, 21-500 Biała Podlaska Indexation: Index Copernicus, AGRO, ProQuest, Polish Medical Bibliography, Polish Ministry of Science and Higher Education. This is an open-access article distributed under the terms of the Creative Common Attribution Non-commercial license (http://creativecommons.org/licenses/by-nc/3.0), which permits use, distribution and reproduction in any medium, provided the original works is properly cited, the use is non-commercial and is otherwise in compliance with the license.
} 


\section{Project Healthy Smile in the Slovak Republic}

\section{Aim}

The main aim of the project is education to health through activists. Activist as a school assistant (SATC School Assistant of Teeth Care) practises education to health with children in pre-school institutions, primary schools, sanatoriums in a way of repeated exercises, 6 times per a school year in each class. The aim of these exercises is to lead children to the right care of their health.

The $1^{\text {st }}$ period of the project begins with care of teeth and gums. That should gradually contribute to reduction of teeth decays in Slovakia.

The $2^{\text {nd }}$ period of the project - prevention of infections, venereal diseases, drug addiction, alcohol, bad habits are gradually involved into the exercises according the age.

This project is based on Swiss project about dental care which has been implementing for 40 years. The result is decline in teeth decays thus 12 years old child has less than one tooth decay on average. It belongs to the best in the world. It has been implementing in Slovakia since 1997 and in the Czech Republic since 1999.

\section{Statistical Evaluation Material and Method}

\section{Comparison Group Tested within Healthy Smile Project at Elementary Schools}

The school dental care assistant - DH students called the schoolchildren of the tested group 6 times in the course of one school year. The school dental care assistant practised with children for the period of 45 minutes. In the course of the practising the school dental care assistant provided children with instructions about the correct technique of teeth cleaning using the Elmex-Gelee toothbrush. Each child was given the toothbrush and the sample of the Elmex toothpaste (approximately $9 \mathrm{ml}$ ). The children were examined during the period of three and six years. To check the effectiveness of the project, the comparison group of children attending the schools not integrated into the prevention project was examined as well.

\section{Epidemiological Examination}

Both groups were examined. Continuous epidemiological examinations were performed in the years 1998, 2001, 2003 and 2009. The examination was implemented with the schoolchildren at the age of 6 -12 years. The level of cariosity was assessed according to the WHO criteria. The condition of oral hygiene was assessed and defined as the condition "almost without dental plaque" (degree 0), "rare dental plaque"(degree 1), and "thick layer of dental plaque" (degree 2).

The schoolchildren of the tested group were examined by one dental practitioner (doc. Dr. Eva Kovalova, PhD.). The schoolchildren of the comparison group were examined by other dental practitioner (Dr. Tatiana Carnoka). Before performing the first examination, both dental practitioners were calibrated in the course of three days; Doc. Dr.Eva Kovalova,PhD. introduced Dr. Tatiana Carnoka into a job. Both groups were equally examined within the same period of time (difference of 1- 2 weeks).

\section{Statistical Processing}

The results concerning the examination of cariosity were processed with respect to the permanent dentition on the basis of (DMFT - KPEZ) index.

To determine the statistical significance the Mann-Whitney Test (tables containing average values) and ChiQuadrat Test (tables containing the percentage evaluation) were used.

\section{Results}

\section{Cariosity of Permanent Dentition}

Figure 1 presents average values of DMF (caries, extraction, tooth filling (KPE)) per tooth of both groups in the period from 1998 to 2009. 


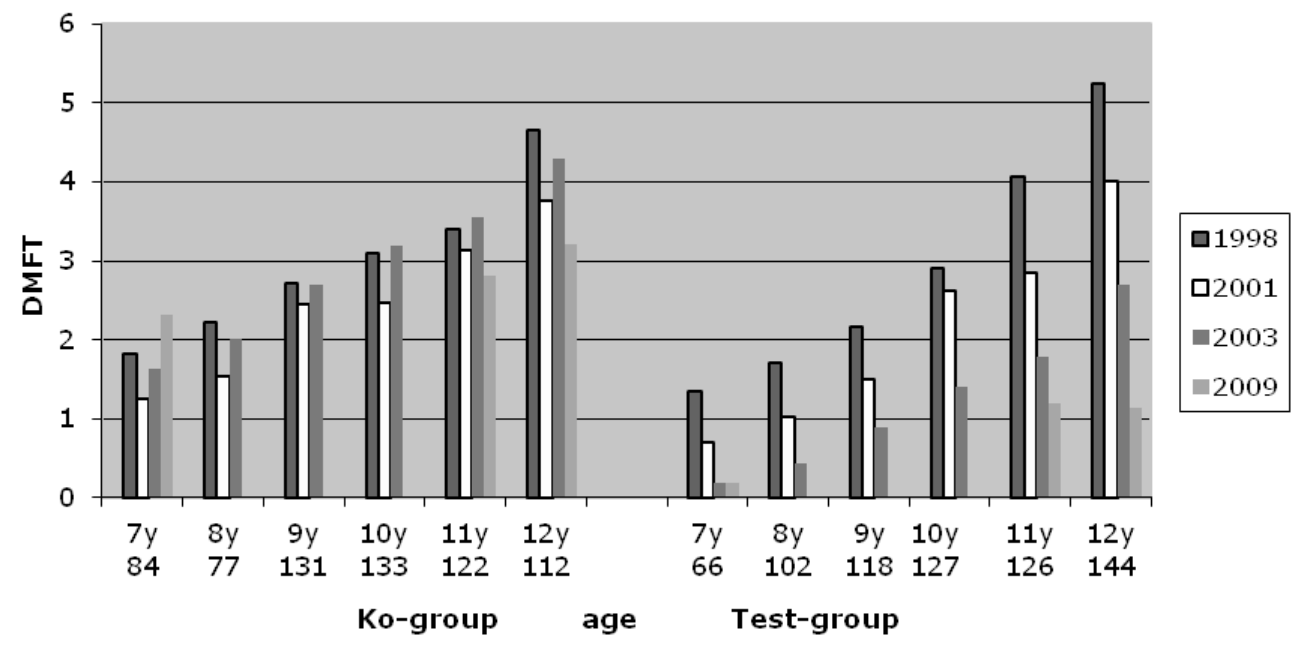

Figure 1. Number of DMF teeth (average value)

The condition of the dentition was similar at the beginning of the examination. When comparing both groups (1998), only the age group of 9-year old children showed the statistical significance. According to „MannWhitney-Test: $\mathrm{P}<0.05$ “ it represents statisitcally important and significant difference.

Within the comparison group there were not present any demonstrable changes in any of the age groups from the year 1998 to the year 2009.

The significant changes concerning the assessment of cariosity were present in all age groups of the tested group. Decrease of average values DMFT depends on age - values between $48 \%$ and $86 \%$ (average decrease is represented by 62\%). The evaluation of the continuous project shows the significant changes in these values of the children at the age of 7, 11 and 12. The changes were from 1998 to $2003-78 \%$, from 2003 to $2009-58 \%$.

\section{Cariosity of Deciduous Dentition}

Figure 2 presents average values of dmf per tooth of both groups in the period from 1998 to 2009.

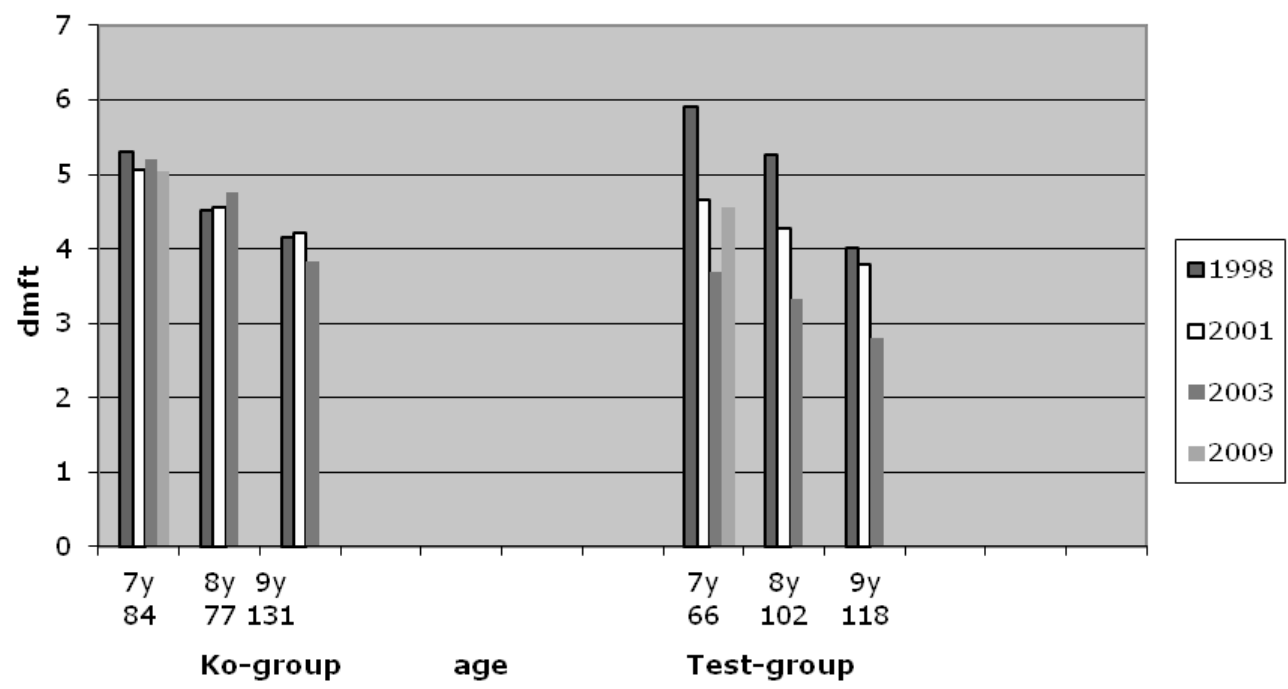

Figure 2. Number of dmf-teeth (average value)

The condition of the dentition of both groups was similar at the beginning of the examination (basic examination in 1998). No changes were found in any age group within the control group in the period from 1998 to 2003. The cariosity decreased significantly in all age groups within the test group (Marthaler 2003). The decrease of the average of the dmft-value was between $30 \%$ and $38 \%$ according to the age. The values of dmft in the group of 7-year old children increased in the year 2009. The reason of this increase is the interruption of the project in this age group because of the unification of schools from 2003-2009. As a consequence, this group also 
contains children who did not participate in the project in their previous schools. This leads to the conclusion that the maintenance of the project without any interruption is essential (WHO: Fluorides and Oral Health).

\section{Conclusion}

The epidemiological study presents successful results of the prevention project Healthy Smile provided that it is performed by trained workers (Dental hygiene Students) and experts in the field of preventive dental medicine such as dental disease prevention officer and dental hygienist. Under supervision of the abovementioned experts, children performed cleaning and fluoridation of their teeth with use of the Elmex-Gelee 6 times a year. Improvement in oral hygiene could be observed within the tested group. High decline of cariosity within the tested group is possible to be explained by influence of more factors at once. Higher quality of teeth cleaning achieved by using the correct technique and higher teeth fluoridation by means of the fluoride product Elmex gelee (Marthaler 2003; Toumba, Curzon 1998).

The thesis presents the way of achieving the WHO objects. It is necessary to involve everyone interested in oral health into the project of Healthy Smile as well as in other projects. And that would be the way to integrate Slovakia among the countries with higher level of oral health.

\section{References:}

1. Jordan D., Fedurcová I., Lenzová L. (2010), Právne následky pri porušení kompetencií v zubnej ambulancii, chyby pri ošetrovaní dentálnym hygienikom. Recenzovaný zborník, Medzinárodný týždeň dentálnej hygieny, FZ PU v Prešove.

2. Klamárová T. (2012), Remineralizačná terapia. DentalCare magazín, 4/12.

3. Lenzová L., Fedurcová L. (2010), Kontinuita v realizácii preventívnych opatrení v skupinovej prevencii. Recenzovaný zborník, Medzinárodný týždeň dentálnej hygieny 2010, FZ PU v Prešove.

4. Marthaler T.M. (2003), Successes and Drawbacks in the Caries-Preventive Use of Fluorides-Lesson to be Learnt from History. Oral Health Prevention Dentistry, Vol. 1,2, pp.129-141.

5. Seppä L. (2001), The Future of Preventive Programs in Countries with Different Systems of Dental Care. Caries Res. 2001,35(suppl. I): 26-29.

6. Toumba K.J., Curzon M.E.J. (1998), Prevention of Occlusal Caries of Children Using Fluoride Slow-Releasing Glass Devices (Abstract No. 3085). J Dent Res 1998,77,1017.

7. WHO: Fluorides and Oral Health (1994), WHO Technical Report Series Geneva.

Submitted: 03.03.2015

Accepted: 04.05.2015 